Article

\title{
Economic and Environmental Potential of Large-Scale Renewable Synthetic Jet Fuel Production through Integration into a Biomass CHP Plant in Sweden
}

\author{
Anton Fagerström $^{1, *}$, Omar Abdelaziz ${ }^{2} \mathbb{D}$, Sofia Poulikidou ${ }^{1}$, Adam Lewrén ${ }^{1} \mathbb{D}$, Christian Hulteberg ${ }^{2} \mathbb{D}_{\text {, }}$ \\ Ola Wallberg ${ }^{2}$ (D) and Tomas Rydberg ${ }^{1}$ (D)
}

1 IVL Swedish Environmental Research Institute, Valhallavägen 81, P.O. Box 210 60, 10031 Stockholm, Sweden; sofia.poulikidou@ivl.se (S.P.); adam.lewren@ivl.se (A.L.); tomas.rydberg@ivl.se (T.R.)

2 Department of Chemical Engineering, Lund University, Naturvetarvägen 14, P.O. Box 124, 22100 Lund, Sweden; omar.abdelaziz@chemeng.lth.se (O.A.); christian.hulteberg@chemeng.lth.se (C.H.); ola.wallberg@chemeng.lth.se (O.W.)

* Correspondence: anton.fagerstrom@ivl.se

check for

updates

Citation: Fagerström, A.; Abdelaziz,

O.; Poulikidou, S.; Lewrén, A.;

Hulteberg, C.; Wallberg, O.; Rydberg,

T. Economic and Environmental

Potential of Large-Scale Renewable

Synthetic Jet Fuel Production through Integration into a Biomass CHP Plant in Sweden. Energies 2022, 15, 1114. https://doi.org/10.3390/en15031114

Academic Editor: Susan van Dyk

Received: 17 January 2022

Accepted: 31 January 2022

Published: 2 February 2022

Publisher's Note: MDPI stays neutral with regard to jurisdictional claims in published maps and institutional affiliations.

Copyright: (c) 2022 by the authors. Licensee MDPI, Basel, Switzerland. This article is an open access article distributed under the terms and conditions of the Creative Commons Attribution (CC BY) license (https:// creativecommons.org/licenses/by/ $4.0 /)$.

\begin{abstract}
The potential of bio-electro-jet fuel (BEJF) production with integration into an existing biomass-based combined heat and power (CHP) facility was investigated. The BEJF is produced via Fischer-Tropsch (F-T) synthesis from biogenic $\mathrm{CO}_{2}$ and $\mathrm{H}_{2}$ obtained by water electrolysis. Technoeconomic (TEA)- and life. cycle (LCA)- assessments were performed to evaluate the production cost and environmental impact of the BEJF production route. The BEJF mass fraction reached $40 \%$ of the total $\mathrm{F}-\mathrm{T}$ crude produced. A reduction of $78 \%$ in heating demands was achieved through energy integration, leading to an increase in the thermal efficiency by up to $39 \%$, based on the F-T crude. The total production cost of BEJF was in the range of EUR 1.6-2.5/liter (EUR 169-250/MWh). The GWP of the BEJF was estimated to be $19 \mathrm{~g} \mathrm{CO}_{2}$-eq per MJ BEJF. The reduction potential in GWP in contrast to the fossil jet baseline fuel varied from $44 \%$ to more than $86 \%$. The findings of this study underline the potential of BEJF as a resource-efficient, cost-effective, and environmentally benign alternative for the aviation sector. The outcome is expected to be applicable to different geographical locations or industrial networks when the identified influencing factors are met.
\end{abstract}

Keywords: electrofuel; sustainable aviation fuel; renewable fuel; carbon capture; techno-economic assessment; life cycle assessment

\section{Introduction}

Pre-COVID-19 aviation was responsible for about $2.4 \%$ of the $\mathrm{CO}_{2}$-emissions stemming from the combustion of fossil jet fuel [1]. If no further measures are taken to temper development, the contribution from the sector is expected to be more than triple until 2050 [2-6]. Although emissions from air transport need to decline drastically, large airplanes and long flights would still need access to energy-dense fuels for the foreseeable future [7]. Policy and legislation systems have started to be implemented for the gradual inclusion of renewable components in aviation fuels, for example, through blending mandates in several countries and possibly also on an EU-level [8-10]. In Sweden, the suggested demand for blending mandate admixture starts at $0.8 \%$ for 2021 , with a gradual increase of up to 27\% for 2030 [8]. The International Civil Aviation Organization (ICAO) assembly recently acknowledged the need for sustainable aviation fuel (SAF) to be developed and deployed in an economically feasible, and a socially and environmentally acceptable way [11]. SAF must have the same qualities and characteristics as conventional jet fuel to be eligible to substitute it. This is important to ensure that existing infrastructure, including aircrafts, engines, fuel delivery networks, and airports can be used, in contrast to alternatives such as $\mathrm{H}_{2}$ or electrification, of which a system redesign is essential. At present, the aviation 
fuel industry focuses on producing SAF as a "drop-in" replacement to conventional jet fuel. The two most widely applied standards to ensure the right jet fuel quality are the American Society for Testing Materials (ASTM) standard numbers D1655 and DEF STAN 91-91 [12]. The Swedish air-travel stakeholders see aviation as a key piece of the puzzle in the direction of becoming the world's first fossil-free welfare country [13]. As the first thematic area in the newly published roadmap for fossil-free aviation [13], the development of liquid fuels is highlighted. More explicitly, they pinpoint: (i) the access to sustainable, locally sourced aviation fuel, (ii) the development of aviation biofuel production technologies, (iii) business models for aviation biofuel development, and (iv) electrofuel development.

There are available amounts of SAFs already today [14], represented mostly by the fat-based hydroprocessed esters and fatty acids (HEFA)-variant [15], an analogue to hydrogenated vegetable oil (HVO) for road transport. Different types of feedstocks can be used for SAFs production, including vegetable oils and agricultural- or forest-based residues [16]. However, the available amounts of such feedstocks are limited. In general, the choice of feedstock affects the climate benefits from the fuel, the amount of fuel that can be produced, and the conversion process efficiency. While considerable Greenhouse gas (GHG) emission savings are demonstrated for SAF produced from biomass residues or waste streams, aviation fuels produced from traditional energy or agricultural crops may lead to significantly higher emissions that are very close to the fossil fuel baseline, indicating a marginal saving or in certain cases even increased impact [16-21]. On the other hand, availability of the waste-based feedstocks used for HEFA and SAF fuels is limited [22,23]. Supply may be strained as demand increases, something that has already become obvious for the Swedish HVO-customers [24,25]. A promising alternative production route for liquid aviation fuel is through electrofuels.

Electrofuels from renewable-based $\mathrm{CO}_{2}$ and $\mathrm{H}_{2}$ are chemically interchangeable with their fossil-based counterparts and require no additional investments in downstream infrastructure or technical changes to the engines in which they will be used. The production potential for electrofuels is that $\mathrm{CO}_{2}$, water, and electricity can be considered abundant raw materials. $\mathrm{CO}_{2}$ can be captured from various industrial processes, such as biofuel production or biomass combustion plants as well as from the air [26]. The amount of $\mathrm{CO}_{2}$ from all feasible point sources in Sweden corresponds to an electrofuel production potential 2-3 times of the current Swedish energy demand for all transportation fuels, which has been around 120 TWh over the past 15 years [26,27]. Similar conclusions for the high potential of electrofuels, especially for aviation, have been drawn for other countries as well, e.g., Germany [28]. SAF in the form of electrofuel produced through Fischer-Tropsch $(\mathrm{F}-\mathrm{T})$ synthesis, described in this paragraph, is allowed today at a maximum blend of $50 \%$ [14].

In this paper, the potential of electro-fuel production in the form of bio-electro-jet fuel (BEJF) is investigated, with integration possibilities into an existing biomass-based combined heat and power (CHP) facility where biogenic $\mathrm{CO}_{2}$ can be retrieved as part of the flue gases. BEJF is produced via Fischer-Tropsch $(\mathrm{F}-\mathrm{T})$ synthesis, from the obtained $\mathrm{CO}_{2}$ combined with $\mathrm{H}_{2}$ that is produced via water electrolysis. The aim is to describe the concept of BEJF production integration with a CHP-plant and quantify its economic and environmental performance from a process systems and life. cycle perspective. As a case study, a production facility located in the northern part of Sweden is examined for applying the technology concept suggested. The study also aims to identify and discuss the underlying conditions that are expected to influence the findings and as such promote or hinder its wider implementation. According to a recently published review [29] there are only a few studies that pinpoint the use of electrofuels for the aviation sector. During the period 2005-2019 a total of 14 papers were published on this subject (e.g. [30-32]), none of which specifically focus on the production integration with an existing CHP-plant. The production integration of BEJF with an existing CHP-plant has, to the best of our knowledge, never been examined in this depth before. Similar conclusions can be drawn for studies on the environmental performance of electrofuels developed as aviation fuels. 
In the review by [33], on environmental impacts of power-to-X systems, only one out of the 32 publications analyzed concerned aviation fuels.

The production facility considered in this work is a new CHP-plant, to be in operation by 2023-2024, at the Lugnvik site, owned and operated by Jämtkraft AB, a major energy provider in Northern Sweden. The setup of the suggested route has been described in an earlier work of the authors [34] and is briefly discussed in this section. Five main steps (or sub-processes) are considered for the BEJF production process.

These five sub-processes make up the BEJF factory and the boundaries are drawn around this system as illustrated in Figure 1 (indicated with a blue dotted line).

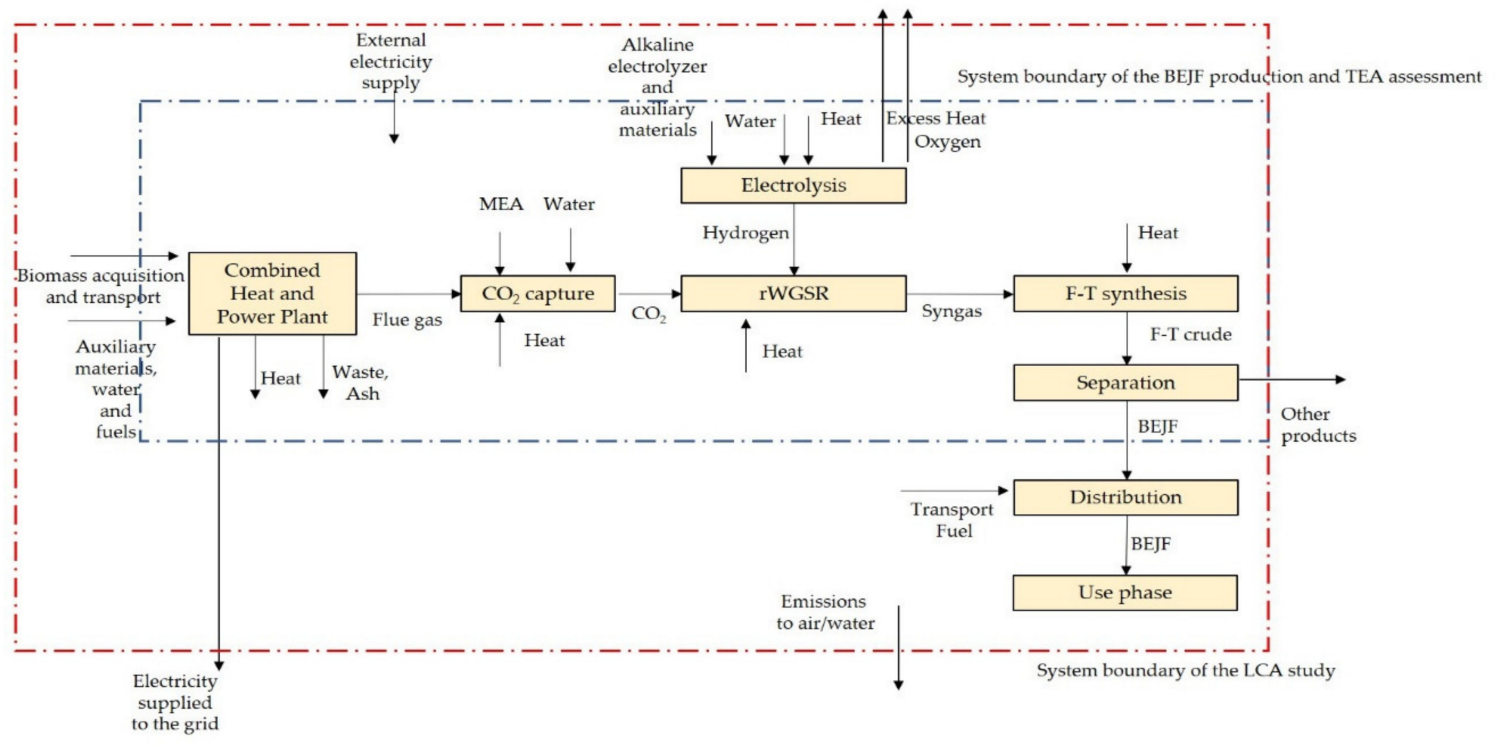

Figure 1. Illustration of the system boundaries applied to this work. The blue dotted line presents the system boundary and unit processes considered for the techno-economic assessment. The red dotted line presents the system boundary of the environmental assessment. Arrows represent the flows of materials, resources, and energy to and within the system and also the flows of energy and emissions from the studied system to the technical and natural environment.

In the concept described in this study, the CHP will go from being a producer of electricity and heat to being a consumer of electricity, but still a producer for heat. This is due to the high amounts of electricity needed to produce hydrogen for the synthesis process. There are several benefits with integrating production of BEJF with an existing biomass-fired CHP as described herein. Firstly, a stand-alone production facility for BEJF would still have needed to be supplied with $\mathrm{CO}_{2}$ from some source and would still have needed large amounts of externally supplied electrical power. Placing a BEJF production plant where both these resources are available is logistically sound. Secondly, cascading use of the large amounts of residual heat from subprocesses and electrolysis would not be possible to the same extent in stand-alone plants. Thirdly, the conversion of biomass is more efficient in large-scale units, where less energy is being lost in the process. Hence, stand-alone facilities are less efficient than an integrated ditto. The electricity supply from the $\mathrm{CHP}$ alone is not sufficient to convert all captured $\mathrm{CO}_{2}$ to BEJF. Hence external electrical power is needed to convert captured $\mathrm{CO}_{2}$ at the scale suggested in this study. This scale can, of course, be altered, but there is a strong economy of scale here, so the BEJF production plant should be as large as possible and have as high operational hours at full capacity as possible. Optimizing these two factors in conjunction with the yearly variations of biogenic $\mathrm{CO}_{2}$ availability from the $\mathrm{CHP}$ due to changing heating demand was an important part of the techno-economic simulation. 


\section{Materials and Methods}

This section describes the methodology, background data, and assumptions used for estimating the total production cost and environmental impact of the suggested BEJF production process.

\subsection{Techno-Economic Assessment}

\subsubsection{Modeling Approach}

The necessary unit operations were simulated using the Aspen Plus ${ }^{\circledR}$ V10 commercial software (Aspen Technology, Inc., Bedford, MA, USA). Three process units were considered after the CHP plant: (1) an amine-based $\mathrm{CO}_{2}$ capture unit, (2) a rWGS reactor, and (3) a F-T synthesis process. The thermodynamic fluid property package used was the nonrandom two-liquid, NRTL, activity coefficient model for the rWGS and the F-T units. The ELECNRTL thermodynamic model was, on the other hand, used for the $\mathrm{CO}_{2}$ capture unit, being a widely accepted property method for simulating chemical absorption of relevant systems due to its versatility [35-37]. The thermodynamic models used were selected according to [38]. The process was modeled based on a biomass feed capacity of $16.5 \mathrm{t} / \mathrm{h}$ dry spruce being burned in the CHP plant. The operating conditions were adjusted to result in a flue gas stream with an $\mathrm{O}_{2}$ level of $\sim 6.15 \% \mathrm{v}$ after treatment to match the real data of the existing CHP plant [39]. Moreover, the Aspen Energy Analyzer ${ }^{\circledR}$ software was used to guide energy integration for the entire process configuration. This can be achieved by integrating the heat sources and the heat sinks within the process to minimize the hot and cold utility requirements (e.g. [40]).

\subsubsection{Cost Determination}

The estimated costs were based on capital (CAPEX) and operational (OPEX) expenditures. The costs at such an early-stage of process design were based on the mass and energy balances obtained for the proposed technology concept to produce BEJF, i.e., using mono-ethanolamine (MEA) for $\mathrm{CO}_{2}$ capture, employing a rWGS reactor for syngas generation, and finally a F-T reactor followed by product upgrading. The individual unit operations were sized based on the flow rates of the mass and energy balances obtained for the process. Having the sizes of the equipment, the installed capital cost was hence estimated with the aid of publicly available costing tools for plant design, including the Aspen Process Economic Analyzer, the Timmerhaus equipment cost estimation tool, and the CAPCOST software. It should be pointed out that it is rather difficult to entirely anticipate the cost structure in a detailed manner, as the technical production of the process is still under development. However, these tools (databases) apply factorial methods to attain the installed cost of various equipment. To give an instance, the installed factor for the electrolyzer was set to 1.2 [41]. All costs were recalculated to the year 2020 using the chemical engineering plant cost index as suggested in the literature [42]. Upon the estimation of the final capital cost, $15 \%$ was added as contingency and $18 \%$ to account for buildings and support structures, which is in-line with the method suggested by Ulrich and Vasudevan [43] for arriving at a green-field installed cost. Based on the preliminary nature of the estimate, no regional differences were taken into account. On the other hand, the production cost of the electrofuel product was estimated, and the main assumptions used were: (i) an electricity price of $€ 49 / \mathrm{MWh}$, based on a $10-\mathrm{y}$ forecast in local electricity prices [44], (ii) a $25 \mathrm{y}$ life span for the proposed plant, (iii) $8400 \mathrm{~h}$ of operation per annum, and (iv) a 5\% weighted average cost of capital (WACC). The production cost of the BEJF product was estimated, and the main assumptions used are summarized in Table 1 [44]. 


\subsubsection{Performance Metric and Sensitivity Analysis}

As a performance evaluation metric, thermal efficiency was used to assess the overall efficacy of the proposed process design, and was calculated using the equation below:

$$
\eta_{\text {thermal }}=\frac{\dot{m}_{B E J F} \times L H V_{B E J F}}{(\text { heat }+ \text { electricity })}
$$

where $\dot{m}_{B E J F}$ is the mass flow rate of the BEJF fraction $(\mathrm{kg} / \mathrm{h}), L H V_{B E J F}$ denotes the lower heating value of the BEJF fraction $(\mathrm{MJ} / \mathrm{kg})$, heat is the hot utility consumption $(\mathrm{MJ} / \mathrm{h})$, and electricity is the electric energy consumption $(\mathrm{MJ} / \mathrm{h})$. Furthermore, sensitivity analysis was carried out to investigate economic aspects, such as the depreciation time, WACC, electricity price, and the investment cost.

Table 1. Assumptions used for economic calculations.

\begin{tabular}{cc}
\hline Parameter & Value \\
\hline Year of capital cost estimate & $\begin{array}{c}2020 \\
\text { Investment cost }\end{array}$ \\
Depreciation & $\begin{array}{c}\text { Sum the unit operation installed cost with } \\
15 \% \text { contingency and } 18 \% \text { buildings and } \\
\text { support structures }\end{array}$ \\
Weighted average cost of capital (WACC) & $\begin{array}{c}25 \text { years in the base case, but varied in the } \\
\text { sensitivity analysis }\end{array}$ \\
Operating hours & $\begin{array}{c}5 \% \text { in the base case, but varied in the } \\
\text { sensitivity analysis } \\
8400 \text { per annum }\end{array}$ \\
Electricity cost & $\begin{array}{c}€ 49 / \mathrm{MWh} \text { in the base case but varied in the } \\
\text { sensitivity analysis. This value is based on a } \\
10-y \text { forecast in local electricity prices * }\end{array}$
\end{tabular}

ata taken from $[44]$

\subsection{Life Cycle Assessment (LCA)}

The environmental performance of the suggested BEJF production route was assessed from a life cycle perspective. Life cycle assessment (LCA) is a well-established approach for estimating the potential environmental impact of a process or service through its life cycle; from material extraction and production to use and final disposal. LCA as a method has been standardized through the ISO 14040 and 14044 series [45,46], although complementary guidelines and policy documents applying the life cycle approach are available. For aviation fuels in particular, the Carbon Offsetting and Reduction Scheme for International Aviation (CORSIA) is established as a life cycle-based methodology for estimating the GHG emissions of SAF [47]. The CORSIA framework and accounting process has been followed in this work. An identified limitation was that the system boundaries when it comes to synthetic fuels and especially fuels based on carbon capture and utilization (CCU) are not specifically addressed. Until now, no established accounting method for such fuels has been available. Attempts to standardize LCAs of at least CCU technologies have been developed by [48] who identified a clear research gap in this area.

The study at hand adopts a cradle-to-grave attributional approach. The system boundary (shown in Figure 1) includes all processes from material (biomass) extraction, transport and processing up to fuel distribution and use. Biomass acquisition and processing at the CHP facility is part of the system boundary of the study as it provides heat to the process along with the flue gas where $\mathrm{CO}_{2}$ is captured from. The functional unit considered is defined as $1 \mathrm{MJ} B E J F$ produced and used in an aircraft engine and having a $L H V$ of $42.8 \mathrm{MJ} / \mathrm{kg}$. The suggested BEJF production route was evaluated in terms of Global Warming Potential-100 years (GWP) expressed in $\mathrm{g} \mathrm{CO}_{2}$-eq. The emission factors for $\mathrm{CO}_{2}, \mathrm{CH}_{4}$, and $\mathrm{N}_{2} \mathrm{O}$ were 1,28 , and 265, respectively, as defined in CORSIA based on the Intergovernmental Panel on Climate Change (IPCC-AR5) [49]. Emissions of biogenic carbon are not considered as well as emissions from combustion of SAF. 


\subsubsection{Inventory Data}

The BEJF production route follows the process described in Section 2 and the same operating conditions described in Section 3.1. Input data was based on actual production data (for the CHP plant) as well as literature data and simulations performed by the authors (for the remaining processes). A summary of key input and output flows is provided in Figure 2. A detailed list of all inventory data can be found in the Supplementary Materials and in Fagerström et al. [34]. The BEJF production process was modeled using the LCA software GaBi v.10 [50]. Generic data from LCI databases were used to model background processes, such as materials production, electricity, and transports.

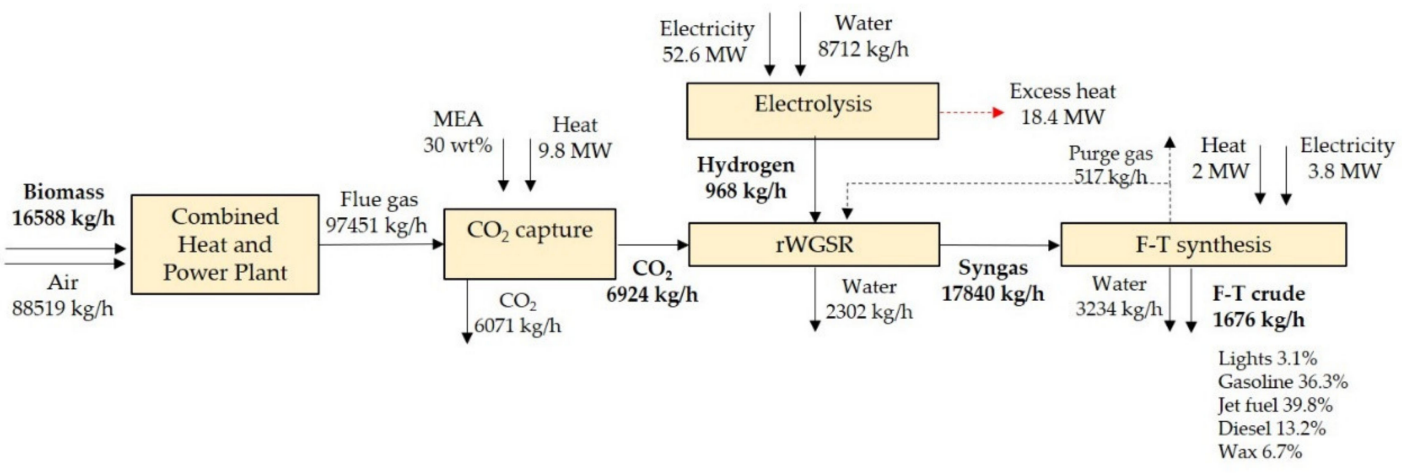

Figure 2. Block flow diagram for the production of BEJF from renewable feedstocks. Material flows of key streams are shown, and the composition of product stream is given in mass\%. (rWGSR, reverse water-gas shift reactor; F-T, Fischer-Tropsch).

The biomass entering the CHP plant consists primarily of dry spruce. An average distance of $90 \mathrm{~km}$ for biomass collection was considered and performed by a EURO 6 Truck-trailer. According to the data obtained, $48 \%$ of the transports are performed with a renewable fuel, and specifically $\mathrm{HVO}$, while the rest with conventional diesel [39]. For modeling the production of $\mathrm{HVO}$, the average feedstock mix used in Sweden for the year 2018 was assumed, based on statistics published by the Swedish Energy Agency [51]. For the CC unit, the same operating conditions and inventory data provided by the technoeconomic analysis (TEA) were applied. Upstream production data on MEA was obtained from generic datasets. The amount of MEA considered in the inventory refers to the amount consumed per $\mathrm{kg} \mathrm{CO}_{2}$ captured, as a major part of MEA is recycled. The electrolysis process was modeled based on literature data in the study from [52]. The electrolyzer was assumed to be manufactured in Germany and transported to Sweden where the BEJF facility is located. The captured $\mathrm{CO}_{2}$ enters the rWGS reactor together with the produced $\mathrm{H}_{2}$ to be converted to syngas for the F-T synthesis step. Energy needs for fuel synthesis and upgrading were determined in this work. For the separation step, where the different fuel and product fractions are obtained, data were taken from Ecoinvent [53] that models a petroleum refinery process. The dataset was modified to align with the process of this work. Data on fuel distribution were based on generic data obtained from JRC [54], estimating an average impact of $0.3 \mathrm{gCO}_{2}$-eq per MJ fuel. For the use phase and for the sake of a simplified comparison to the fossil baseline, a $100 \%$ renewable blend was assumed, despite today's maximum $50 \%$ limit. The GWP of the fossil baseline was $89 \mathrm{~g} \mathrm{CO}_{2}$-eq/MJ for jet fuel [47].

\subsubsection{Key Assumptions for the LCA}

Apart from being the $\mathrm{CO}_{2}$ source, the $\mathrm{CHP}$ plant provides heat to the consecutive stages of the process. Energy-based allocation was applied to account for the multifunctional process of the CHP plant where heat and electricity are normally produced. The $\mathrm{CO}_{2}$, however, is assumed to bear only the emissions from the CC process and not upstream (flue gas production). The electricity demands during the different stages of the BEJF production process are covered by an external electricity source assuming a $100 \%$ renewable 
mix consisting of hydro and wind power representing the electricity mix provided in the region (Jämtkraft 2020). As discussed above, the electricity needs cannot be covered by the CHP plant, thus an external source was required. During the hydrolysis step, oxygen and heat are produced along with $\mathrm{H}_{2}$. These co-products are not utilized in the reference case thus no allocation was applied. As such, $\mathrm{H}_{2}$ accounts for all upstream impacts from the electrolysis step. Alternative scenarios were considered as part of the scenario analysis explained in the following section. The purged gas stream from F-T synthesis is assumed to be recycled back to the CHP plant, and thus no emissions to air were considered. Finally, as shown in Figure 2, F-T crude consists of various products apart from the BEJF fraction (composed of hydrocarbons from $\mathrm{C}_{10}$ to $\mathrm{C}_{15}$ ). Allocation using the energy content (on LHV basis) of the co-products (being primarily gasoline and diesel equivalents) is used to estimate the impact of the BEJF. For details see also the Supplementary Materials.

\subsubsection{Scenario Analysis}

Three additional scenarios were investigated to increase the understanding of the parameters and aspects that may influence the performance of the suggested approach Electrolysis is an energy intense step where considerable amounts of electricity are expected to be needed. The electricity mix in the reference case assumed a $100 \%$ renewable mix that is available to the facility. Different policy documents, however, may require accounting of alternative mixes that are based on national or regional levels. The Swedish electricity mix (consisting primarily of nuclear and hydro power) is therefore assumed as a representative mix in this case study for policy analysis. When it comes to the outputs of the electrolysis process, two additional scenarios are presented: one including the utilization of excess heat and another one where both heat and oxygen are considered. In both cases, allocation is used to handle multifunctionality. When only heat is considered as a co-product along with hydrogen production, energy-based allocation is applied. With an LHV of $120 \mathrm{MJ}$ per $\mathrm{kg} \mathrm{H}_{2}$, an allocation factor of 0.69 was obtained. In terms of environmental performance, this implies that $69 \%$ of the upstream impacts from $\mathrm{H}_{2}$ production were allocated to $\mathrm{H}_{2}$. When both heat and oxygen were considered as co-products of the electrolysis step, economic allocation was applied. Prices representing a Swedish case of 50 SEK $/ \mathrm{kg}$ [55], $7.5 \mathrm{SEK} / \mathrm{kg}$ [56], and 0.24 SEK/MJ [57] were applied for hydrogen, oxygen, and heat (as district heating), respectively. The allocation factor in this case was estimated to 0.41 , implying that $41 \%$ of the upstream impacts from $\mathrm{H}_{2}$ production were allocated to $\mathrm{H}_{2}$.

\section{Results}

\subsection{Mass and Energy Balances}

Mass and energy balances were obtained for the proposed process design. A simplified block flow diagram for the entire BEJF synthetic route is shown in Figure 2, while the process flow diagram is depicted in Figure S1 in Supplementary Materials. The cold flue gas stream from the CHP plant (Table 2 gives a detailed composition of the stream) is first washed in an absorber column with a lean amine solution (a water solution containing $30 \mathrm{wt} \% \mathrm{MEA}$ ) at an inlet temperature of $40^{\circ} \mathrm{C}$. The rich, $\mathrm{CO}_{2}$-loaded amine solution is then sent to a stripper column, where the reaction of the MEA is reversed, liberating $\mathrm{CO}_{2}$ at a temperature of $106^{\circ} \mathrm{C}$. The concentrated $\mathrm{CO}_{2}$ is hence mixed with $\mathrm{H}_{2}$ from the electrolyzer units that is generated by the electric splitting of water. The mixture of $\mathrm{CO}_{2}$ and $\mathrm{H}_{2}$ is heated to $900{ }^{\circ} \mathrm{C}$ in a rWGS reactor that is modeled as an equilibrium reactor using the REquil module, passing through a catalyst. The endothermic reaction is favored by high reaction temperatures and is governed by chemical equilibrium.

$$
\mathrm{CO}_{2}+\mathrm{H}_{2} \rightleftharpoons \mathrm{CO}+\mathrm{H}_{2} \mathrm{O}
$$


Table 2. Composition of cold flue gas stream.

\begin{tabular}{ccc}
\hline Component & Mass Flow $(\mathbf{k g} / \mathbf{h})$ & Mass $\%$ \\
\hline Water & 7558 & 7.8 \\
CO2 & 14,657 & 15.0 \\
O2 & 7523 & 7.7 \\
N2 & 67,703 & 69.5 \\
Others & 10 & $<0.1$ \\
Total & 97,451 & 100.0 \\
\hline
\end{tabular}

* Other components include traces of nonvolatiles, $\mathrm{NO}_{\mathrm{x}}, \mathrm{CO}$, ash, stilbene, and resins.

After the rWGS reaction takes place, the syngas-rich stream is cooled in a condenser and the water produced is separated in a flash drum. Subsequently, the resulting mixture of $\mathrm{CO}, \mathrm{CO}_{2}$, and $\mathrm{H}_{2}$ is isentropically compressed to 30 bars in three stages and is heated to $220{ }^{\circ} \mathrm{C}$ prior to entering a second catalytic reactor, where the $\mathrm{F}-\mathrm{T}$ reaction occurs. Specifically, $\mathrm{CO}$ and $\mathrm{H}_{2}$ are converted into longer alkane and alkene hydrocarbons by means of the F-T synthesis. The F-T reactor was an isothermal plug flow reactor, RPlug module, applying power-law kinetics. The $\alpha$-value in the Anderson-Schulz Flory distribution was 0.8 to minimize the formation of methane and lower hydrocarbons and to obtain a suitable fraction of jet fuel $[58,59]$ The low-temperature conditions also favor the production of liquid fuels [60].

$$
\begin{gathered}
(2 n+1) \mathrm{H}_{2}+n \mathrm{CO} \rightarrow \mathrm{C}_{n} \mathrm{H}_{2 n+2}+n \mathrm{H}_{2} \mathrm{O} \\
2 n \mathrm{H}_{2}+n \mathrm{CO} \rightarrow \mathrm{C}_{n} \mathrm{H}_{2 n}+n \mathrm{H}_{2} \mathrm{O}
\end{gathered}
$$

After F-T synthesis, the effluent is cooled, water is condensed, and the non-condensable gases are separated, employing a flash separation model operating at $25^{\circ} \mathrm{C}$ to result in a F-T crude as a final product. On the other hand, the unreacted $\mathrm{CO}, \mathrm{CO}_{2}$, and $\mathrm{H}_{2}$ are recycled back to the process, with the exclusion of a minor bleed-off stream (constituting $1 \%$ of the inlet mass flow of $\mathrm{H}_{2}$ ), in order to circumvent the accumulation of inerts in the recycle loop. The bleed-off stream could potentially be used as a fuel in the integrated $\mathrm{CHP}$ facility. Continuous purging has also been applied in a similar research effort for F-T synthesis to avoid the build-up of inerts [61]. The total F-T crude output was estimated to be $1676 \mathrm{~kg} / \mathrm{h}$. The BEJF fraction $\left(\mathrm{C}_{10}-\mathrm{C}_{15}\right)$ had the highest mass distribution in the product mixture, reaching up to $40 \%$. Such a fraction (cut) is mostly compatible with the American Society for Testing Materials (ASTM) standards of the conventional jet fuel Jet A/A1, i.e., in the boiling point range of $158-269^{\circ} \mathrm{C}$ [62]. The second fraction was the gasoline $\left(\mathrm{C}_{5}-\mathrm{C}_{9}\right)$, showing a mass distribution of approximately $36 \%$. Other co-products included light hydrocarbons $\left(\mathrm{C}_{2}-\mathrm{C}_{4}\right) 3 \%$, diesel $\left(\mathrm{C}_{16}-\mathrm{C}_{18}\right) 13 \%$, and waxes $7 \%$. Other components included trace amounts of $\mathrm{CO}_{2}, \mathrm{CO}, \mathrm{CH}_{4}, \mathrm{H}_{2} \mathrm{O}, \mathrm{H}_{2}, \mathrm{~N}_{2}$, and $\mathrm{O}_{2}$. Only hydrocarbons until $\mathrm{C}_{20}$ were considered in this study; $\mathrm{C}_{19}$ and $\mathrm{C}_{20}$ being in the wax fraction.

\subsection{Energy Integration}

Compared to a stand-alone production facility for synthetic fuels, the deep-integrationconcept with a biomass fed CHP has several potential benefits: (i) access to large amounts of biogenic $\mathrm{CO}_{2}$ that enhance the environmental performance of the electrofuel product and enables high production volumes, (ii) access to operational and auxiliary services that can be adjusted to include the operation of the BEJF plant, (iii) potential of integration of mass- and energy flows that increases the overall system efficiency of the integrated plant, (iv) potential to use the district heating network as heat-sink for residual heat from the BEJF production process that ensures that energy is not being wasted in the integrated process. Electricity and heat are the major sources of energy required in the BEJF process. The electricity is not considered to be part of the energy integration between the CHP plant and the BEJF process. Electricity will be supplied from the grid and not from the CHP plant per se, being insufficient to supply the BEJF process with needed electricity. The major heating and cooling demands for the BEJF process are summarized in Table 3, and the hot and cold Composite Curves for the process can be seen in Figure 3. 
Table 3. Stream data of the BEJF process.

\begin{tabular}{|c|c|c|c|}
\hline Unit & $T_{\text {in }}\left({ }^{\circ} \mathrm{C}\right)$ & $T_{\text {out }}\left({ }^{\circ} \mathrm{C}\right)$ & Duty (MW) \\
\hline Electrolyzer & 80 & 80 & -18.4 \\
\hline $\mathrm{CO}_{2} / \mathrm{MEA}$ heater & 54 & 96 & 8.1 \\
\hline Stripper condenser & 25 & 24 & -3.6 \\
\hline Stripper reboiler & 105 & 106 & 9.8 \\
\hline rWGS & 24 & 900 & 15.3 \\
\hline Syngas cooler & 900 & 25 & -15.1 \\
\hline F-T heater & 70 & 220 & 2.0 \\
\hline $\mathrm{F}-\mathrm{T}$ & 220 & 220 & -6.6 \\
\hline F-T cooler & 220 & 25 & -4.1 \\
\hline
\end{tabular}

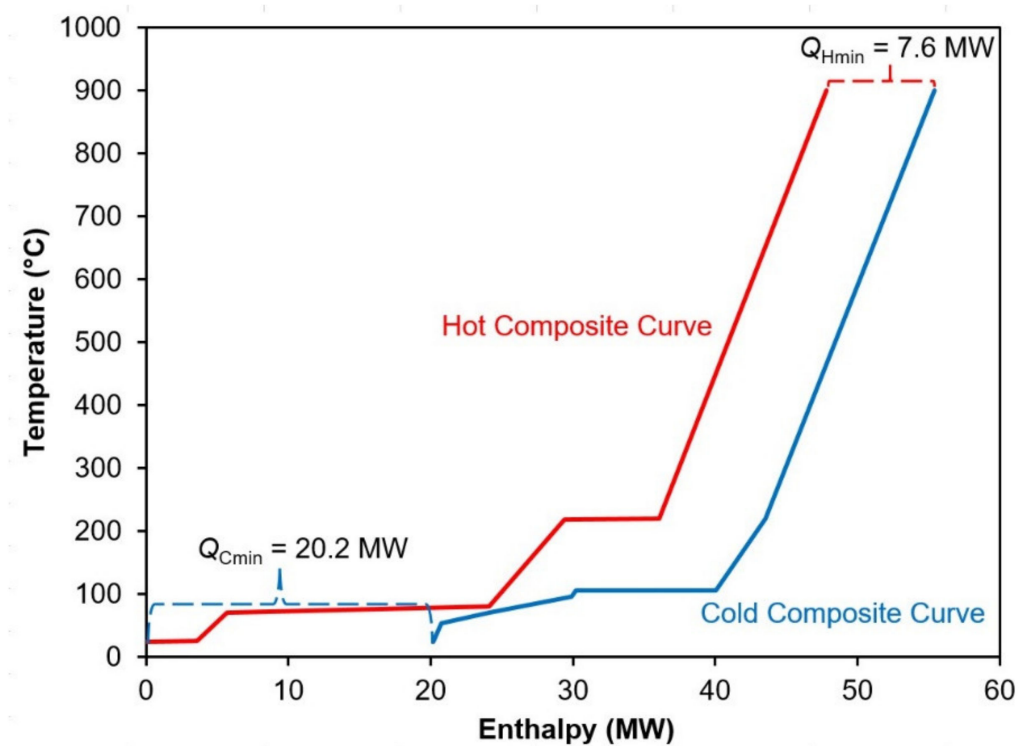

Figure 3. Composite curves for the heat exchange stream data of the BEJF process at $\Delta T_{\min }=10^{\circ} \mathrm{C}$.

The minimum energy requirements for hot and cold utilities (Energy Targets) were calculated using Aspen Energy Analyzer ${ }^{\circledR}$, considering a minimum temperature approach difference $\left(\Delta T_{\min }\right)$ of $10^{\circ} \mathrm{C}$. The integration of the BEJF process would require that the CHP plant is operated at a slightly higher load, which would also lead to a higher electricity production from the CHP plant compared to a non-integrated scenario. Process integration between the two processes will lead to a primary energy demand for the BEJF process of 7.6 MW, as compared to $35.2 \mathrm{MW}$ for a non-integrated case. This corresponds to a significant potential saving in energy of $78 \%$ with respect to heating demands. The hightemperature heat could be provided via the combustion of tail gas. About $15 \mathrm{MW}$ is returned to the district heating network at lower temperatures reducing the load of the CHP plant, thereby freeing up capacity in that process.

\subsection{Economic Evaluation and Process Performance}

To better assess the costs of operating a unit of the type described above, estimates of both the CAPEX and the OPEX were performed. The largest investment in the plant was attributed to the electrolyzers. A 53 MW electrolyzer installation is larger than the current state-of-the-art and will thus consist of multiple units in parallel. There are several values available in the literature for the investment cost of the technology, and for the estimate, a cost of $511 € / \mathrm{kW}$ was used [41]. This value is in the lower end of the interval suggested 
in the literature. In addition to the investment cost of the electrolyzers, there is also an installation factor for these to arrive at the installed cost. This is estimated to 1.2, which brings the overall investment to approximately $€ 32 \mathrm{M}$. Second only to the electrolyzer investment is the compressor installation, which was estimated at an installed cost of $€ 3 \mathrm{M}$. The remaining equipment was approximated to $\sim € 8 \mathrm{M}$, and in addition to these costs, the contingency $(€ 6.2 \mathrm{M})$ and support facilities ( $€ 9.9 \mathrm{M})$ were added, giving a total investment cost of $€ 59 \mathrm{M}$. The investment cost breakdown is represented in Figure 4. Using an initial assumption of $5 \%$ with respect to the WACC and a $25 \mathrm{y}$ economic lifetime results in a yearly capital cost of $€ 4.2 \mathrm{M}$ (interest rate and depreciation).

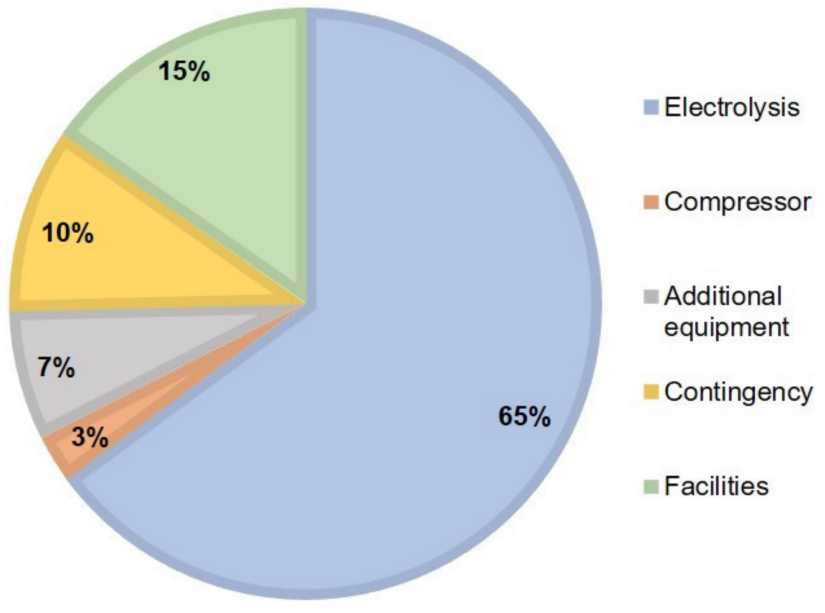

Figure 4. The CAPEX breakdown of the BEJF process.

With respect to the OPEX, the biggest share comes from the electricity used in the electrolyzers. The consumption of electricity is on the order of $60 \mathrm{MW}$, with the majority going to the electrolyzer and the compressor. This makes the cost of the electricity the main factor in assessing the overall production cost of the product. The $60 \mathrm{MW}$, over the $8400 \mathrm{~h}$ operational period required, are priced at $€ 49 / \mathrm{MWh}$, totaling $€ 24.7 \mathrm{M}$ per year. The production cost of BEJF product was in total $€ 169 / \mathrm{MWh}$, with $84 \%$ of the cost stemming from the operating cost and the balance $16 \%$ from the investment cost. This is equivalent to about $€ 1.6 /$ litreBEJF. This estimation for production cost is fairly competitive when compared to fossil fuel production cost that is usually in the range of $€ 36-50 / \mathrm{MWh}$, especially when the sustainability aspects are considered. However, the costs for distribution and storage systems should be further evaluated to identify the overall cost-competitiveness compared to other transportation fuel alternatives [26]. The production cost estimated was within the range of the predicted costs for electrofuels by 2030 presented in other studies $€ 160-210 / \mathrm{MWh}$ of fuel [26], where the production cost of $\mathrm{H}_{2}$ was a major influencing parameter. Moreover, the process performance reached thermal efficiencies of about $8 \%$ based on the BEJF fraction only for the non-integrated case $(20 \%$ based on the F-T crude product mixture) and $22 \%$ (39\% based on the F-T crude product mixture) for the heat-integrated scenario, which is consistent with earlier studies [63,64]. To assess the sensitivity of the production cost, the most critical parameters were evaluated for better understanding of their effects on the system. The sensitivity analysis was performed by changing one variable at a time and assessing the impact of each variable on the cost of production. Increasing the capital cost of the electrolyzers to $€ 1008 / \mathrm{kW}$, which is still within the suggested range of CAPEX, will significantly impact the cost of the plant. The overall investment cost will increase to $€ 116 \mathrm{M}$, and the production cost will increase to $€ 195 / \mathrm{MWh}$. The effect of changing the depreciation and the interest rate is depicted in Figure 5.

As can be seen, there is a small effect on the cost of production as a function of both the WACC and of the depreciation time. However, the volatility is clearly demonstrated upon varying the cost of electricity (Figure 6). Lowering the electricity price by about $40 \%$ 
would lower the production cost by almost $€ 60 / \mathrm{MWh}$ and a corresponding $40 \%$ increase would increase the price by the equal amount.
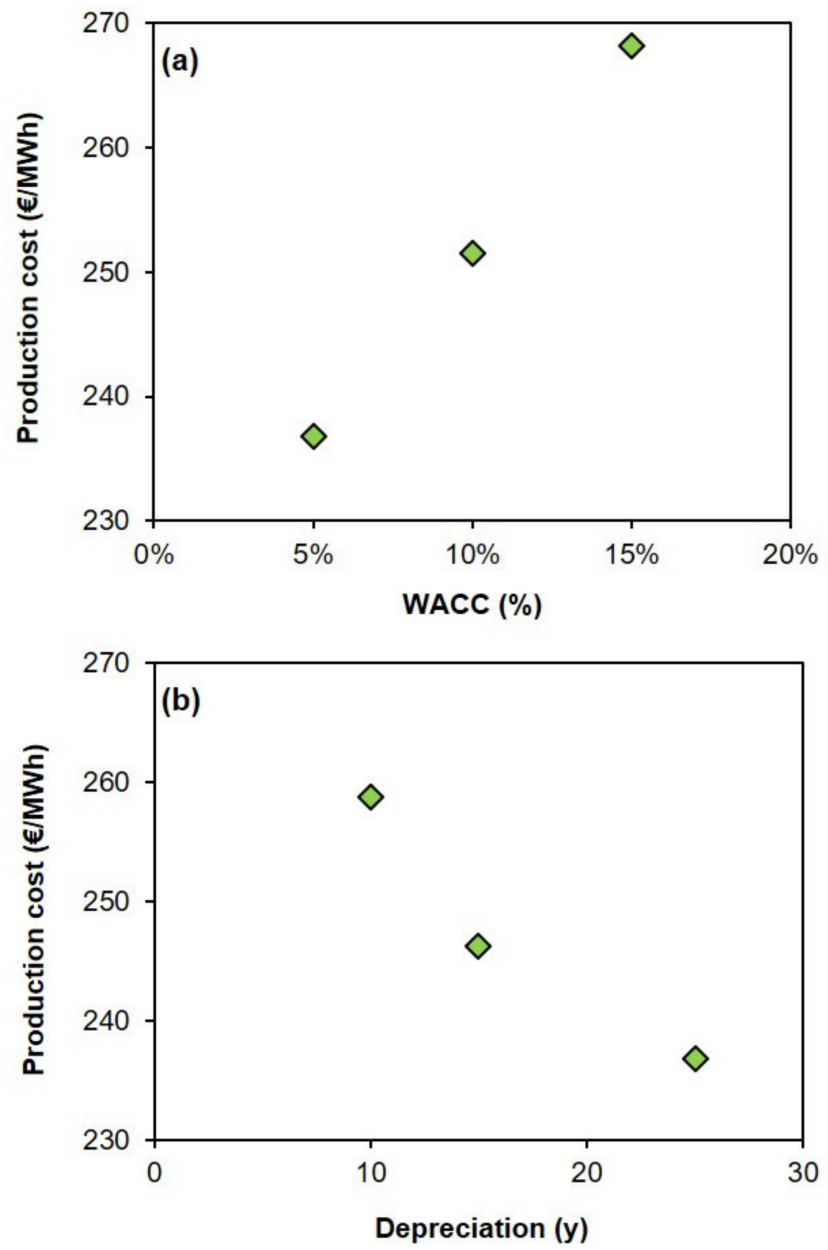

Figure 5. Effects of varying (a) WACC and (b) depreciation on the fuel production cost.

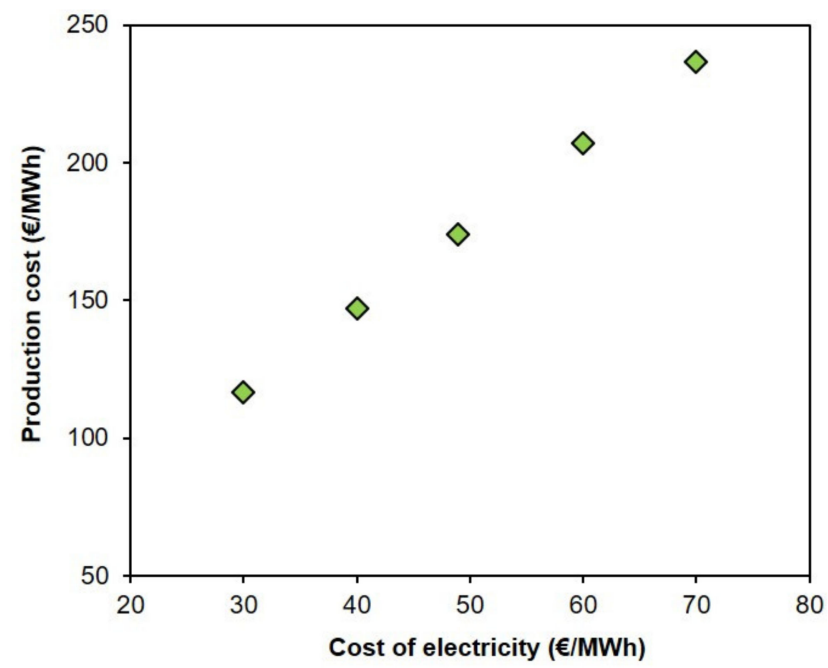

Figure 6. Effects of varying the cost of electricity on the fuel production cost.

\subsection{Life Cycle Environmental Performance}

The results related to the impact on climate change of the BEJF process are demonstrated in Figures 7 and 8 . Figure 7 focuses on the production stage and the different process 
units considered to produce $1 \mathrm{MJ}$ of BEJF, whereas in Figure 8, the distribution and use stage are included along with a comparison to the fossil and renewable counterparts.

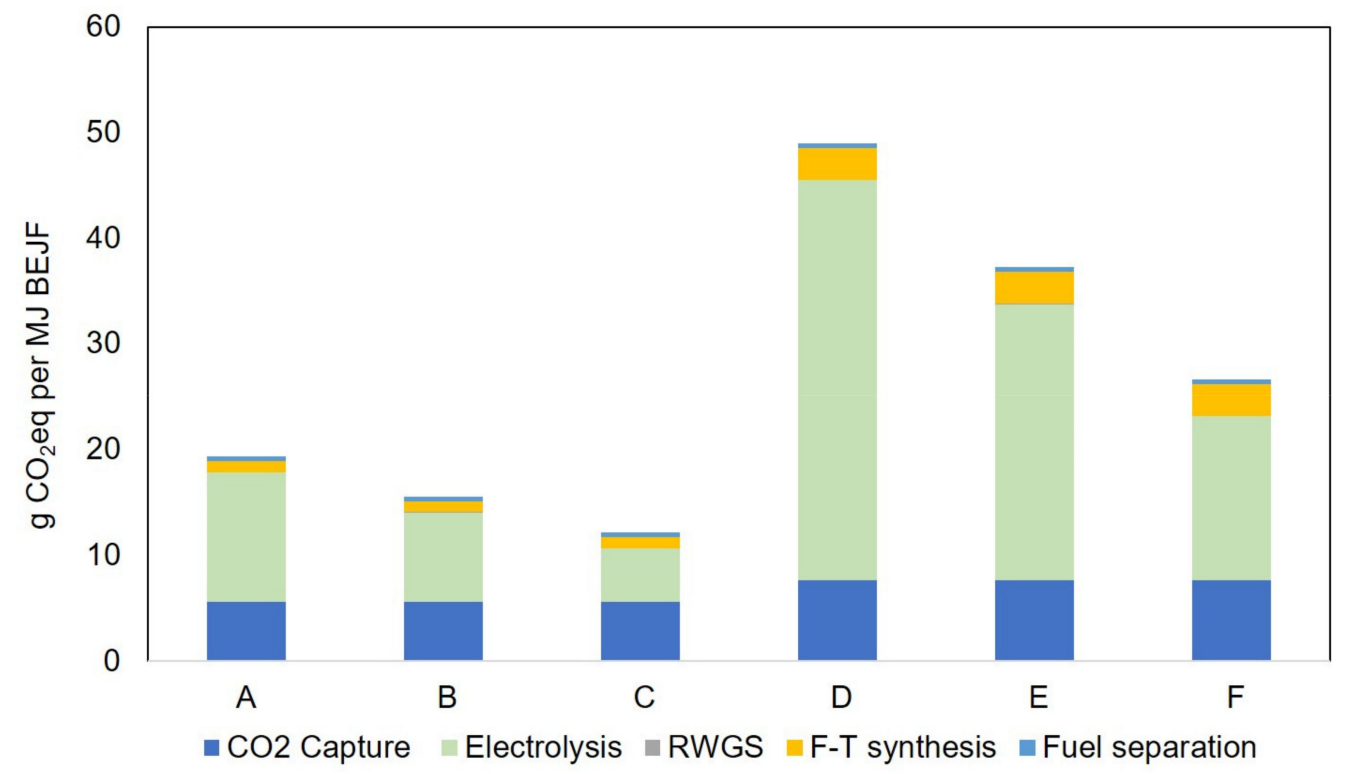

Figure 7. GHG emissions expressed as Global Warming Potential (GWP 100 years) resulting from the production of 1 MJ of BEJF. (A) Renewable electricity (reference scenario), (B) Renewable electricity (heat utilization scenario), (C) Renewable electricity (heat and oxygen utilization scenario, economic allocation), (D) Average Swedish electricity mix, (E) Average Swedish electricity mix (heat utilization scenario), (F) Average Swedish electricity mix (heat and oxygen utilization scenario, economic allocation).

The GWP from the production of $1 \mathrm{MJ} \mathrm{BEJF}$ amounts to $19.4 \mathrm{~g} \mathrm{CO}_{2}$-eq for the reference case. Among the different process units, $\mathrm{H}_{2}$ production via electrolysis accounts for the highest emission share (almost $62 \%$ of the total GHG emissions). Despite assuming a pure renewable electricity mix in that step (consisting of hydropower and wind power), emissions associated to power production, distribution, and losses seem to influence the overall result. A high potential to decreased total impact is observed when the byproducts from the electrolysis step are effectively utilized. In the two alternative cases, when heat and oxygen are considered and utilized as co-products, a 19\% to 37\% reduction in the total impact is obtained (as illustrated also in Figure 7).

The high electricity demand is discussed as one of the potential bottlenecks of electrofuels production [65], an aspect that drives the economic viability and the environmental performance of the produced BEJF. Shifting to the Swedish electricity mix would increase the total GWP of the BEJF by $60 \%$ in the reference case as shown in Figure 7 . However, the Swedish average electricity mix can still be considered an electricity mix with low carbon intensity, as it consists primarily of hydro power, nuclear power, and other renewable sources [66]. This stresses the importance of access to green electricity when electrofuel production is concerned.

From a life cycle perspective, the proposed BEJF exhibits lower emissions compared to the fossil baseline for all scenarios considered. The emission reduction potential varies from $44 \%$ (when the Swedish electricity mix is considered) to more than $86 \%$ when renewable electricity in combination to co-products exploitation is considered (Figure 8). Those GHG emission reductions are comparable and in certain cases lower to traditional HEFA and other SAF fuels, as shown in Figure 8, based on the default values reported in [47]. 


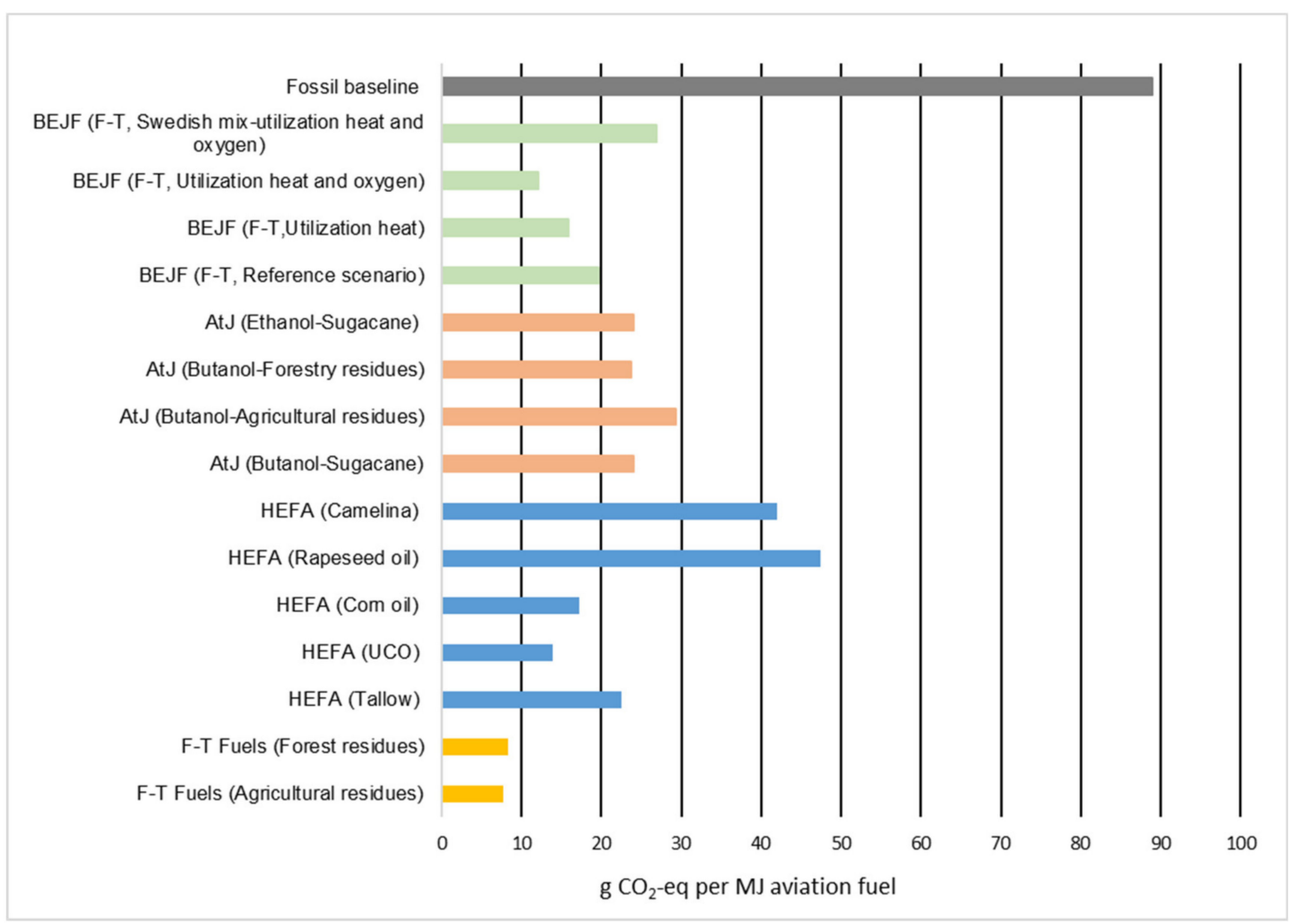

Figure 8. Comparison of the Global Warming Potential (GWP) of the investigated BEJF alternative to selected fossil and renewable aviation fuels. AtJ = Alcohol to Jet, BEJF: Bio-electro-jet fuel, F-T= Fischer-Tropsch, HEFA = Hydroprocessed Esters and Fatty Acids, UCO = Used Cooking Oil.

The study on which this paper reports the findings of is an early-stage assessment where the technology concept is not yet applied on-site. This means that the results are drawn from calculations and simulations and not based on an existing process. Subsequently, this approach could potentially lead to uncertainties, including under- or overestimations in the data reported. On the other hand, key parameters are identified in the study and provide a possibility for improvements once the facility has been established. A future assessment of the concept in a demo- or a full-scale production plant would provide an even deeper understanding on the factors influencing the techno-economic and environmental performance of these fuels. Moreover, there is still room for improvement in optimizing the operating conditions, the integrational aspects, and the energy-efficiency of the CC and the F-T processes towards a higher BEJF-yield.

\section{Discussion and Conclusions}

Electrofuels have gotten increased attention as renewable and energy-dense liquid aviation fuels. This paper describes a BEJF synthesis route that is integrated into a CHP-plant in the northern part of Sweden. The CHP plant provides a direct source of biogenic $\mathrm{CO}_{2}$ and a high potential for increased process efficiency. The performance of the suggested production route has been investigated from a techno-economic and environmental life cycle perspectives, showing that the proposed process can fulfil the emission reduction targets and provide a promising and cost-effective alternative for the aviation sector. Electrofuels demonstrate high GHG emissions reduction potential, and compared to many of the first-generation biofuels, electrofuels do not compete with food or feed production systems. Compared to a stand-alone production facility for synthetic fuels, the deepintegration-concept offers both economic and environmental benefits [26]. Certain criteria, however, need to be met, as also shown in this work, such as access to renewable and low-cost electricity, access to biogenic carbon, and increased utilization of side-streams and co-products. 
Countries that have a strong bio-based industry (i.e., forestry, pulp, and paper), and/or an energy sector that utilizes biomass for co-generating heat and electricity, are expected to have many relevant point-sources of available biogenic $\mathrm{CO}_{2}$ that are currently not utilized. Moreover, the point sources with excess heat or sources connected to a heat production facility have the additional benefit of providing offset for residual heat streams, effectively boosting the electrofuel production system overall efficiency. It is important to treat product streams other than BEJF, including gasoline, diesel, and waxes as useful co-products as this enhances the economic viability of the process. Electrofuel production is a form of industrial $\mathrm{H}_{2}$ usage. Increased industrial $\mathrm{H}_{2}$ usage has been pinpointed as one of the cornerstones in enabling the European transition towards a $\mathrm{H}_{2}$ society [67]. This is partly due to the additional effects such a plant could have on the surrounding societies' accelerated use of $\mathrm{H}_{2}$ and the establishment of other $\mathrm{H}_{2}$-based infrastructure and industries, such as filling-stations or industrial raw-material, once there is a close-by available source for it. The electrolyzer employed for $\mathrm{H}_{2}$ production for electrofuels can, together with storage facilities, be scaled in such a way to make its operation adjustable. This would enable the facility to take a role in balancing services for the electric power system, a service likely highly sought after in a future electricity supply scenario with increased share of intermittent power production [68].

The aviation sector will need access to energy-dense hydrocarbon-based liquid fuels for the foreseeable future. The concept presented in this paper could help to satisfy that need, and potentially drastically decrease the climate-impact from air-travel. Prior to COVID-19, the Swedish market used around 1.35 million $\mathrm{m}^{3}$ of jet fuel annually [7], which corresponds to around 1.09 million metric tons. The amounts produced from the individual facility concerned in this study would produce around 27,000 tons of BEJF, which would satisfy about $5 \%$ of the annual need as a $50 \%$ admixture. This alone would fulfil half of the reduction obligation quota [8] for 2025. However, the potential for additional facilities is there, and the need from the aviation sector for renewable fuels could be met in a combination with other types of SAF. The proposed process concept could be integrated with an existing CHP plant as well as the district heating network to achieve an improved overall energy efficiency. Further research is required to increase the BEJF portion in the product fraction, as well as to assess the influence of varying the capacity of biomass feed and key operating conditions on the economic and environmental indicators.

Supplementary Materials: The following are available online at https:/ / www.mdpi.com/article / 10.3390/en15031114/s1, Table S1: Process and life cycle inventory data used for the biomass CHP plant in northern Sweden. The data were provided by Jämtkraft AB and represent a standalone CHP plant, i.e., prior to any integration; Table S2: Process and life cycle inventory data used for $\mathrm{CO} 2$ capture using monoethanolamine (MEA). Data were estimated in this work and are presented per kg CO2 captured; Table S3: Process and life cycle inventory data used to model the production of $1 \mathrm{~kg} \mathrm{H} 2$ via water electrolysis; Table S4: Process and life cycle inventory data used to model the production of $1 \mathrm{~kg}$ syngas via rWGS. Process data were estimated in this work; Table S5: Process and life cycle inventory data used to model the production of $1 \mathrm{~kg}$ BEJF based on F-T synthesis. Process data were estimated in this work; Figure S1: Process flow diagram for the production of BEJF from renewable feedstock. (CHP, combined heat and power; MEA, monoethanolamine; rWGSR, reverse water-gas shift reactor; F-T, Fisher-Tropsch).

Author Contributions: Conceptualization, A.F., O.A., S.P., C.H., O.W. and T.R.; Methodology, O.A., S.P., C.H., O.W. and T.R.; Software, O.A., S.P., C.H. and O.W.; Validation, O.A., S.P. and A.L.; Formal analysis, A.F., O.A., S.P., A.L., C.H. and O.W.; Investigation, A.F., O.A., S.P. and A.L.; Validation, A.F., C.H. and O.W.; Data curation, A.F., O.A. and S.P.; Writing-original draft preparation, A.F., O.A., S.P., C.H. and O.W.; Writing-review and editing, A.F., O.A., S.P., C.H., O.W. and T.R.; Visualization, O.A., S.P., A.L., C.H. and O.W.; Supervision, A.F., S.P., C.H., O.W. and T.R.; Project administration, A.F., C.H. and O.W.; Funding acquisition, A.F., C.H., O.W. and T.R. All authors have read and agreed to the published version of the manuscript.

Funding: This research was funded by the Swedish Energy Agency (Grant 48387-1), the SIVL Foundation for IVL (Grant 3D:09/19 and 3D:09/20), and the Jämtkraft Environmental fund. 
Data Availability Statement: The data presented in this study are available on request from the corresponding author.

Acknowledgments: This work was conducted in close collaboration with Jämtkraft, Chalmers University of Technology, Fly Green Fund, Nordic Initiative for Sustainable Aviation, the Power Region, and the Municipality of Östersund. The authors would like to thank all actors involved for their contributions and fruitful discussions.

Conflicts of Interest: The authors declare that the research was conducted in the absence of any commercial or financial relationships that could be construed as a potential conflict of interest.

\section{References}

1. Graver, B.; Zhang, K.; Rutherford, D. CO2 Emissions from Commercial Aviation. 2018. Available online: https: / theicct.org/ sites/default/files/publications/ICCT_CO2-commercl-aviation-2018_20190918.pdf (accessed on 16 January 2022).

2. Kousoulidou, M.; Lonza, L. Biofuels in aviation: Fuel demand and $\mathrm{CO}_{2}$ emissions evolution in Europe toward 2030. Transp. Res. Part D Transp. Environ. 2016, 46, 166-181. [CrossRef]

3. Lu, C. When will biofuels be economically feasible for commercial flights? Considering the difference between environmental benefits and fuel purchase costs. J. Clean. Prod. 2018, 181, 365-373. [CrossRef]

4. Schäfer, A.W.; Evans, A.D.; Reynolds, T.G.; Dray, L. Costs of mitigating $\mathrm{CO}_{2}$ emissions from passenger aircraft. Nat. Clim. Change 2016, 6, 412-417. [CrossRef]

5. Ang, A.W.X.; Rao, A.G.; Kanakis, T.; Lammen, W. Performance analysis of an electrically assisted propulsion system for a short-range civil aircraft. Proc. Inst. Mech. Eng. Part G J. Aerosp. Eng. 2019, 233, 1490-1502. [CrossRef]

6. The International Air Transport Association. Now for Something Completely Different. 2019. Available online: https://www. airlines.iata.org/analysis/now-for-something-completely-different (accessed on 30 August 2021).

7. SOU. Biojet för Flyget. Betänkande av Utredningen om Styrmedel för att Främja Användning av Biobränsle för Flyget. 2019 Available online: https:/ / www.regeringen.se/4a9e8c/contentassets/6d591e58fd9b4cad8171af2cd7e59f6f/biojet-for-flyget-sou201911 (accessed on 16 January 2022).

8. Proposition 2020/21:135. Reduktionsplikt för Flygfotogen, Swedish Parliament. 2021. Available online: https:/ /www.riksdagen. se/sv/dokument-lagar/dokument/proposition/reduktionsplikt-for-flygfotogen_H803135 (accessed on 16 January 2022).

9. 2030-Sekretariatet. 2020. Available online: https://www.mynewsdesk.com/se/2030-sekretariatet/pressreleases/2030 -sekretariatet-klara-besked-om-reduktionsplikten-viktigt-steg-foer-klimatomstaellningen-av-transportsektorn-3033961 (accessed on 4 June 2021).

10. Deane, J.P.; Pye, S. Europe's ambition for biofuels in aviation-A strategic review of challenges and opportunities. Energy Strategy Rev. 2018, 20, 1-5. [CrossRef]

11. ICAO. Sustainable Aviation Fuels (SAF). 2020. Available online: https://www.icao.int/environmental-protection/pages/SAF. aspx (accessed on 3 June 2021).

12. IATA. IATA Fact Sheet 2 Sustainable Aviation Fuel: Technical Certification. 2020. Available online: https://www.iata.org/ contentassets /d13875e9ed784f75bac90f000760e998/saf-technical-certifications.pdf (accessed on 16 January 2022).

13. Fossilfritt Flyg 2045. Fossil-Free Aviation 2045-Actions Obstacles and Needs. 2020. Available online: https://www.diva-portal. org/smash/get/diva2:1523447/FULLTEXT01.pdf (accessed on 16 January 2022).

14. ICAO. ICAO Global Framework for Aviation Alternative Fuels. 2021. Available online: https://www.icao.int/environmentalprotection/GFAAF/Pages/default.aspx (accessed on 4 June 2021).

15. Research and Markets. Sustainable Aviation Fuel Market by Fuel Type, Biofuel Manufacturing Technology, Biofuel Blending Capacity, Platform, Region-Global Forecast to 2030. 2020. Available online: https:/ / www.prnewswire.com/news-releases/ sustainable-aviation-fuel-market-by-fuel-type-biofuel-manufacturing-technology-biofuel-blending-capacity-platform-region--global-forecast-to-2030-301162865.html (accessed on 4 June 2021).

16. Prussi, M.; Lee, U.; Wang, M.; Malina, R.; Valin, H.; Taheripour, F.; Velarde, C.; Staples, M.D.; Lonza, L.; Hileman, J.I. CORSIA: The first internationally adopted approach to calculate life-cycle GHG emissions for aviation fuels. Renew. Sustain. Energy Rev. 2021, 150, 111398. [CrossRef]

17. O'connell, A.; Kousoulidou, M.; Lonza, L.; Weindorf, W. Considerations on GHG emissions and energy balances of promising aviation biofuel pathways. Renew. Sustain. Energy Rev. 2019, 101, 504-515. [CrossRef]

18. De Jong, S.; Antonissen, K.; Hoefnagels, R.; Lonza, L.; Wang, M.; Faaij, A.; Junginger, M. Life-cycle analysis of greenhouse gas emissions from renewable jet fuel production. Biotechnol. Biofuels 2017, 10, 64. [CrossRef]

19. Pierobon, F.; Eastin, I.L.; Ganguly, I. Life cycle assessment of residual lignocellulosic biomass-based jet fuel with activated carbon and lignosulfonate as co-products. Biotechnol. Biofuels 2018, 11, 139. [CrossRef]

20. Van Dyk, S.; Su, J.; Ebadian, M.; O'connor, D.; Lakeman, M.; Saddler, J. Potential yields and emission reductions of biojet fuels produced via hydrotreatment of biocrudes produced through direct thermochemical liquefaction. Biotechnol. Biofuels 2019, 12, 1-12. [CrossRef]

21. Han, J.; Tao, L.; Wang, M. Well-to-wake analysis of ethanol-to-jet and sugar-to-jet pathways. Biotechnol. Biofuels 2017, 10, 21. [CrossRef] [PubMed] 
22. Poulikidou, S.; Heyne, S.; Grahn, M. A comparative assessment of current and future fuels for the transport sector. In Proceedings of the European Biomass Conference and Exhibition Proceedings, Online, 14-17 May 2018. [CrossRef]

23. Karlsson, K.; Poulikidou, S.; Henryson, K.; Hammar, T.; Hansson, J. HVO Produced from Swedish Raw Materials-Current and Future Potentials. f3centre. 2020. Available online: https:/ f3centre.se/app/uploads/P46980-1_FDOS-07-2020_Report-201211 _FINAL.pdf (accessed on 16 January 2022).

24. Swedish Energy Agency. Övervakningsrapport Avseende Skattereduktion för Flytande Biodrivmedel under Perioden Januari Till Och Med Juni 2020. 2020. Available online: https://www.energimyndigheten.se/remissvar-och-uppdrag/Download/ ?documentName=2020-000417\%20\%20\%C3\%96vervakningsrapport\%20halv\%C3\%A5r\%202020.pdf\&id=1706 (accessed on 16 January 2022).

25. Peck, P.; Grönkvist, S.; Lönnqvist, T.; Voytenko, Y. Systemic Constraints and Drivers for Production of Forest-Derived Transport Biofuels in Sweden-Part A, f3-The Swedish Knowledge Centre for Renewable Transportation Fuels, Göteborg, Sweden. 2016. Available online: https:/ / f3centre.se/app/uploads/Final_f3-2016-09A_Peck-et-al_161012-1.pdf (accessed on 16 January 2022).

26. Brynolf, S.; Taljegard, M.; Grahn, M.; Hansson, J. Electrofuels for the transport sector: A review of production costs. Renew. Sustain. Energy Rev. 2018, 81, 1887-1905. [CrossRef]

27. Swedish Energy Agency. Energianvändning i Transportsektorn (Inrikes och Utrikes) Uppdelad per Bränsleslag, 1970-, Energimyndighetens Statistikdatabas. 2021. Available online: http:/ / pxexternal.energimyndigheten.se/pxweb/sv/Transportsektorns\%20 energianv\%C3\%A4ndning/- /EN0118_1.px/ (accessed on 16 January 2022).

28. Drünert, S.; Neuling, U.; Zitscher, T.; Kaltschmitt, M. Power-to-Liquid fuels for aviation-Processes, resources and supply potential under German conditions. Appl. Energy 2020, 277, 115578. [CrossRef]

29. Dahal, K.; Brynolf, S.; Xisto, C.; Hansson, J.; Grahn, M.; Grönstedt, T.; Lehtveer, M. Techno-economic review of alternative fuels and propulsion systems for the aviation sector. Renew. Sustain. Energy Rev. 2021, 151, 111564. [CrossRef]

30. Schmidt, P.; Batteiger, V.; Roth, A.; Weindorf, W.; Raksha, T. Power-to-Liquids as Renewable Fuel Option for Aviation: A Review. Chem. Ing. Tech. 2018, 90, 127-140. [CrossRef]

31. Goldmann, A.; Sauter, W.; Oettinger, M.; Kluge, T.; Schroder, U.; Seume, J.R.; Friedrichs, J.; Dinkelacker, F. A Study on Electrofuels in Aviation. Energies 2018, 11, 392. [CrossRef]

32. Schmidt, P.; Weindorf, W.; Roth, A.; Batteiger, V.; Riegel, F. Power-to-Liquids Potentials and Perspectives for the Future Supply of Renewable Aviation Fuel, German Environment Agency, Berlin. 2016. Available online: https://www.umweltbundesamt.de/en/ publikationen/power-to-liquids-potentials-perspectives-for-the (accessed on 16 January 2022).

33. Koj, J.C.; Wulf, C.; Zapp, P. Environmental impacts of power-to-X systems-A review of technological and methodological choices in Life Cycle Assessments. Renew. Sustain. Energy Rev. 2019, 112, 865-879. [CrossRef]

34. Fagerström, A.; Grahn, D.; Lundberg, S.; Ghosh, S.; Creaser, D.; Olsson, L.; Abdelaziz, O.; Wallberg, O.; Hulteberg, C.; Poulikidou, S.; et al. Large scale bio electro jet fuel production integration at CHP-plant in Östersund, Sweden. IVL Swedish Environmental Research Institute. Report B2407. 2021. Available online: https:/ /www.ivl.se/english/ivl/publications/publications/ large-scale-bio-electro-jet-fuel-production-integration-at-chp-plant-in-ostersund-sweden.html (accessed on 16 January 2022).

35. Ayittey, F.K.; Saptoro, A.; Kumar, P.; Wong, M.K. Energy-saving process configurations for monoethanolamine-based CO2 capture system. Asia-Pacific J. Chem. Eng. 2021, 16, e2576. [CrossRef]

36. Li, X.; Wang, S.; Chen, C. Experimental and rate-based modeling study of CO2 capture by aqueous monoethanolamine. Greenh Gases Sci. Technol. 2014, 4, 495-508. [CrossRef]

37. Udara, S.A.; Kohilan, R.; Lakshan, M.; Madalagama, M.L.; Pathirana, P.P.; Sandupama, P.S. Simulation of carbon dioxide capture for industrial applications. Energy Rep. 2020, 6, 659-663. [CrossRef]

38. Carlson, E. Don't gamble with physical properties for simulations. Chem. Eng. Prog. 1996, 92, 35-46.

39. Jämtkraft; Heat Department, Östersund, Sweden. Personal communication, 2020.

40. Smith, R. Chemical Process Design and Integration; John Wiley \& Sons: Hoboken, NJ, USA, 2016.

41. Eichman, J.; Townsend, A.; Melaina, M. Economic Assessment of Hydrogen Technologies Participating in California Electricity Markets; Publishers International Linking Association: Lynnfield, MA, USA, 2016.

42. Brown, T. Engineering Economics and Economic Design for Process Engineers; CRC Press: Boca Raton, FL, USA, 2016.

43. Ulrich, G.; Vasudevan, P. Chemical Engineering Process Design and Economics a Practical Guide; Process Publishing: Durham, NH, USA, 2004.

44. Jämtkraft; Electricity Department, Östersund, Sweden. Personal communication, 2020.

45. 14040:2006; Environmental Management_Life Cycle Assessment_Principles and Framework. International Organization for Standardization (ISO): Geneva, Switzerland, 2006.

46. 14044:2006; Environmental Management—Life Cycle Assessment-Requirements and Guidelines. International Organization for Standardization (ISO): Geneva, Switzerland, 2006.

47. ICAO. CORSIA Methodology for Calculating Actual Life Cycle Emissions Values. 2019. Available online: https://www.icao.int/ environmental-protection/pages/SAF_LifeCycle.aspx (accessed on 16 January 2022).

48. Müller, L.J.; Kätelhön, A.; Bachmann, M.; Zimmermann, A.; Sternberg, A.; Bardow, A. A Guideline for Life Cycle Assessment of Carbon Capture and Utilization. Front. Energy Res. 2020, 8, 15. [CrossRef]

49. Intergovernmental Panel on Climate Change (IPCC). AR5 Climate Change 2014: Mitigation of Climate Change. Available online: http://www.ipcc.ch/report/ar5/wg3/ (accessed on 16 December 2021). 
50. Thinkstep, A.G. GaBi Software System and Database for Life Cycle Engineering 1992-2018 Version 10; LBP-University of Stuttgart: Stuttgart, Germany, 2021.

51. Swedish Energy Agency. Drivmedel 2018: Redovisning av Rapporterade Uppgifter Enligt Drivmedelslagen, Hållbarhetslagen och Reduktionsplikten. 2018. Available online: https:/ / www.energimyndigheten.se/globalassets/fornybart/hallbara-branslen/ publikationer/drivmedel-2018.pdf?ResourceId=5753 (accessed on 16 January 2022).

52. Koj, J.C.; Wulf, C.; Schreiber, A.; Zapp, P. Site-Dependent Environmental Impacts of Industrial Hydrogen Production by Alkaline Water Electrolysis. Energies 2017, 10, 860. [CrossRef]

53. Jungbluth, N.; Melli, C.; Wenzel, P. Life Cycle Inventories of Oil Refinery Processing and Products. ESU-Services Ltd. Commissioned by BFE; BAFU, Erdöl-Vereinigung: Schaffhausen, Switzerland, 2018.

54. European Commission. European Platform on Life Cycle Assessment. 2020. Available online: https:/ / eplca.jrc.ec.europa.eu/ (accessed on 16 January 2022).

55. Vätgas Sverige. 2021. Available online: https://www.vatgas.se/ (accessed on 15 September 2021).

56. Mohseni, F.; Görling, M.; Lindén, M.; Larsson, M. Genomförbarhetsstudie för Power to Gas på Gotland, Energiforsk Media, Stockholm. 2017. Available online: https:/ / energiforskmedia.blob.core.windows.net/media/22491/genomforandestudie-forpower-to-gas-pa-gotland-energiforskrapport-2017-378.pdf (accessed on 16 January 2022).

57. Energiföretagen Sverige. Fjärrvärmepriser. 2020. Available online: https://www.energiforetagen.se/statistik/fjarrvarmestatistik/ fjarrvarmepriser/ (accessed on 29 September 2021).

58. Tunå, P. Generation of Synthesis Gas for Fuels and Chemicals Production; Lund University: Lund, Sweden, 2013. Available online: https:/ /lucris.lub.lu.se/ws/files/6234654/3732073.pdf (accessed on 16 January 2022).

59. Tunå, P.; Hulteberg, C. A new process for well-head gas upgrading. J. Nat. Gas Sci. Eng. 2013, 13, 1-6. [CrossRef]

60. Hansen, N.H.; Pedersen, T.H.; Rosendahl, L.A. Techno-economic analysis of a novel hydrothermal liquefaction implementation with electrofuels for high carbon efficiency. Biofuels Bioprod. Biorefining 2019, 13, 660-672. [CrossRef]

61. Hannula, I.; Kaisalo, N.; Simell, P. Preparation of Synthesis Gas from $\mathrm{CO}_{2}$ for Fischer-Tropsch Synthesis-Comparison of Alternative Process Configurations. C 2020, 6, 55. [CrossRef]

62. Zhao, X.; Sun, X.; Cui, X.; Liu, D. Production of biojet fuels from biomass. Sustain. Bioenergy 2019, 127-165. [CrossRef]

63. Atsonios, K.; Kougioumtzis, M.-A.; Panopoulos, K.D.; Kakaras, E. Alternative thermochemical routes for aviation biofuels via alcohols synthesis: Process modeling, techno-economic assessment and comparison. Appl. Energy 2015, 138, 346-366. [CrossRef]

64. Marchese, M.; Buffo, G.; Santarelli, M.; Lanzini, A. $\mathrm{CO}_{2}$ from direct air capture as carbon feedstock for Fischer-Tropsch chemicals and fuels: Energy and economic analysis. J. CO2 Util. 2021, 46, 101487. [CrossRef]

65. Graves, C.; Ebbesen, S.D.; Mogensen, M.B.; Lackner, K.S. Sustainable hydrocarbon fuels by recycling $\mathrm{CO}_{2}$ and $\mathrm{H}_{2} \mathrm{O}$ with renewable or nuclear energy. Renew. Sustain. Energy Rev. 2011, 15, 1-23. [CrossRef]

66. Swedish Energy Agency. Energy in Sweden 2020. An Overview, Swedish Energy Agency, Eskilstuna, Sweden. 2020. Available online: https:/ / www.energimyndigheten.se/en/news/2020/an-overview-of-energy-in-sweden-2020-now-available/ (accessed on 16 January 2022).

67. European Commission. A Hydrogen Strategy for a Climate-Neutral Europe. 2020. Available online: https://ec.europa.eu/ energy/sites/ener/files/hydrogen_strategy.pdf (accessed on 20 July 2021).

68. Dyab, L.; Bondesson, P.-M.; Sköldberg, H.; Holm, J.; Brolin, M.; Nyström, S.; Samuelsson, R. Sektorskoppling för ett mer Effektivt Energisystem, Energiforsk, Stockholm, Sweden. 2020. Available online: https:/ / energiforsk.se/program/sektorkoppling-el-gasoch-fjarrvarme/ rapporter/sektorkoppling-for-ett-mer-effektivt-energisystem-2021-764/ (accessed on 16 January 2022). 